\title{
FOREIGN DIRECT INVESTMENT AND InSTITUTIONAL ADEQUACY: NEW GRANGER Causality EVIDENCE FROM AFRICAN COUNTRIES
}

Adewale R Aregbeshola

Department of Business Management, University of South Africa

Accepted: April 2014

\begin{abstract}
The strategic importance of foreign direct investment in the contemporary economies has been tremendous. While various countries (developed and developing economies) have benefitted from the direct and spillover effects of FDI, which range from improved technology and knowledge diffusion through to individual and corporate capability enhancement, FDI outflow remains largely channelled to the developed countries, and the rapidly developing countries in Asia and South America. Evidence suggests that the developmentenhancing effects of FDI are felt more highly in the developing economies, such as economies in Africa. However, FDI inflow to the developing economies has been very low. Using data generated from the African Development Indicators (ADI) between 1980 and 2008 in econometric estimations, this paper finds that government policies (especially fiscal and monetary policies) play significant roles in facilitating FDI inflow to the African countries studied. The study thereby suggests an improved regulatory framework to make Africa more attractive to inflow of FDI.
\end{abstract}

Key words: foreign direct investment, Africa's economic development, regulatory framework, multinational corporations

JEL: D22, E02, F13

1

\section{Background} information/introduction

Previous studies on the determinants of FDI inflow have largely been focussed on the developed and emerging economies (Culem, 1988; Billington, 1999; Asiedu, 2002; Asheghian, 2004). While a few studies have tried to cover some regions or countries in Africa (Alfaro, Chanda, Kalemli-Ozcan \& Sayek, 2004; Adam $\&$ Tweneboah, 2009), none of these studies have specifically targeted a great number of African countries as done in this study. Also, the country-specific dynamics (like controlling for resource endowment), which forms a part of the contribution of this study to the body of existing knowledge, are rarely engaged in those studies are rarely discussed in those studies.

International investment, an advanced state of international trade, allows for the efficient allocation of global resources in order to reap comparative location-specific advantages in the production of goods and services (Steers \& Nardon, 2006). This asseveration lends credence to the need for countries and corporate bodies to specialise in the production of those goods and services that would yield location comparative advantages and import those goods and services that would yield comparative disadvantages (Hill, 2013). This process, among others, has enhanced international trade and has furthered the drive to seek competitively expedient offshore locations with potential sustainability.

Previous studies on the motivation for offshore investments have been premised largely on competition pressure. For example, Porter (1990) observes that national prosperity is created through national values, culture, economic structures, institutions and histories. $\mathrm{He}$ states further that differences in these factors contribute to the competitive success of any nation because they form the basis of the nation's competitive advantage. These resources combined, Porter argues, will result in a sustainable national competitive advantage. 
Through competitive advantage, a country would be able to acquire and leverage operational and organisational competencies that would further catalyse its advancement and superiority (Schmitz, 2007). A competitive country would, through revolutionary changes in national incomes, production techniques and improved operational processes, develop absorptive capacity that would enable it benefit from technological advances in international infrastructure like banking, ICTs, insurance, and transportation (Caves, 1996; Asheghian, 2004). Such developments have somewhat facilitated both the opportunities to learn about investment opportunities abroad and the means to reap those benefits (Korth, 1985).

Based on this analysis, the findings of David Ricardo (comparative advantage), HeckscherOhlin's (factor proportions), through to Porter's Competitive Advantage of Nations all clearly establish the practical inevitability of foreign investment as the foundation upon which a nation's growth and prosperity can be built. More importantly and recently, multinational corporations (MNCs) are globally acclaimed as the conduit through which global trade and investment are conducted. MNCs play a very critical role in shaping modern investment history. MNCs, using their tools of foreign expansion (FDIs), represent an increasingly important element of global commerce and factor mobility (Rivera-Batiz \& Oliva, 2003; Correa \& Kumar, 2003). They usually pervade host nations through the inflow of bundles of resources like capital, production techniques, organisational and managerial skills, marketing know-how and market access. MNCs can therefore be expected to contribute more to the host nation's growth than the domestic investments (Peng, 2009). Conclusively, MNCs play a very critical role in dictating the contemporary trading and investment arrangements, and in most cases, they improve human prosperity in the host countries (Ashegian, 2004; Caves, 2007; Hill, 2013).

\section{2}

\section{MNCs and global trade and} investment

The principle of foreign direct investment took its evolution from a series of economic theories, especially the theory of the multinational enterprise (MNCs) (Dunning, 1988; Caves, 1996; Levi, 2009). The theory of MNC in itself took its root from two different schools of thoughts, namely the locationspecific advantage theory, and the industrial organisation theory, which form the springboard for this study. The location-specific theory postulates that MNCs will locate in a host country that exhibits unique comparative advantage over the other locations (Porter, 1990; Barro \& Sala-i-Martin, 1995; Steers \& Nardon, 2006). These advantages may be resources, market, human capital, technology, geophysics or favourable political economy. Given that the overarching driver of offshore investment is the desire to attain sustainable competitive advantage over competitors, the consideration accorded these competitive elements differs from one organisation to another.

Further, the location-specific advantage theory is a useful determinant of the direction of FDI flow. The theory emphasises geographical economic advantages, which MNCs attempt to achieve, by dispersing their investment and production portfolios across geographies (Hood \& Young, 1979; Dunning; 1988; Buckley, 1990). The earlier Japanese and Indian automobile investors in the United States adopted this approach. Singer sewing machine also adopted the same strategy at the early stage of its overseas expansion (Hill, 2013). Some of the competitive advantages that MNCs enjoy over domestic competitors include the use of advanced technology, lower sunk cost in research and development, better administrative and marketing skills and access to low-cost funding for capital projects (Asheghian, 2004; Peng, 2009). It is further suggested that favourable investment environments in offshore locations are capable of engendering financial market stability. This could accrue favourable interest- and exchangerate differentials for foreign investors (Levi, 2009).

The industrial organisation theory, on the other hand, bears on the gains that could be derived from competition between the domestic organisations in the host country and foreign investors (Hood \& Young, 1979; Caves, 1996; Hill, 2013). This theory suggests 
that domestic firms will benefit from the presence of MNCs in the host market through spillover mechanism, which occurs as they interact in a way that improves their managerial expertise, technological advancement and operational processes (Barro \& Sala-i-Martin, 1995; Steers \& Nardon, 2006).

Overseas investment by multinational corporations (MNCs) always forms a strategic part of national economic strategy of not only the developed countries, but the developing countries as well (Stiglitz \& Charlton, 2005; Hill, 2013). As a result, institutional supports are garnered to advance the prosperity of multinationals by both the home and host governments (Stiglitz, 2002). On a global scale, the significance of investment cannot be over emphasised. For example, the global value of investments was quoted at about US $\$ 650$ billion between the 1970s and 1980s, more than six times the value of US\$105 billion for 1967 (UNCTAD, 2009:xxi). As suggested by the same source, the figures have risen to a very high level in recent times - a momentum that is expected to project into the future. For instance, the world investments rose from US\$710.8 billion in 2004 to US\$1.7 trillion in 2011 UNCTAD, 2013::xxi). However, the stock reduced to US\$1.4 trillion in 2012, of which the developing world attracted US\$703 billion. Out of these increases, Africa's stock grew from US\$44 billion in 2010 to US\$50 billion in 2012, which still represents less than three percent share of the global stock (UNCTAD, 2013:3).

Specifically today, there are about 82000 multinational corporations worldwide, with overseas subsidiaries amounting to about 810 000 (UNCTAD, 2009). These enterprises and their foreign affiliates play a significant role in shaping the landscape of the world economy a role that continues to grow in stature. According to the UNCTAD (2009), exports by foreign affiliates of multinational enterprises are estimated to have accounted for about a third of the total world exports of goods and services between 2009 and 2012, and the number of people employed by these enterprises worldwide was more than 12 percent of the world population in 2008. These significant roles indicate why countries across the world initiate sustainable policy frameworks that will not only attract these multinationals into their countries, but also retain them (Akinkugbe, 2005).

\section{3}

\section{Determinants of FDI destination}

Studies have been conducted to understand the determinants of FDI destination. For instance, Chakrabarti (2001:91-92) compiled previous work done on the determinants of FDI direction. In that study, the author categorised these factors into basic captions on a scale ranging from positive through to negative and insufficient. He evaluated the findings of various authors along a continuum of eight explanatory variables, namely market size, labour cost, trade barrier, growth rate, economic openness, trade deficit, exchange rate volatility, and tax. While the overall finding was inconclusive on the strength and explanatory power of most of these variables, variables like market size, growth rate, and economic openness are of positive significance in the studies evaluated. Asiedu (2002) also compiled 29 previous studies on the impact of six explanatory variables for a country's attractiveness to inflow of foreign investment. While her finding exhibited some deviation from the findings of Chakrabarti, she concurred that factors that influence capital productivity gains, essentially those that revolve around regulatory framework, are positively significant in determining a country's attractiveness to inflow of foreign investment. Alfaro et al. (2004) also did a similar study where the role of the local financial market was established as a determinant of the absorptive capacity of the southern Africa host countries.

\section{4 \\ Conceptual framework}

Choosing the most appropriate theoretical launch pad for this study was very challenging. This is mainly due to the fact that FDI itself serves divergent purposes for the host and home governments, and for the investing multinational corporation itself. To start with, the investing multinational corporations have a profit maximisation objective as the prime reason for taking the risk of offshore 
investment. Conversely, the home countries support and give institutional backing to offshore expansion of MNCs on the ground that such an investment will repatriate funds from their offshore subsidiaries, increase demand for resources from the home country, and further the hegemony of the home country in the global manufacturing activities. On the other hand, host countries initiate favourable investment policies in the hope that such inflow will boost the supply of capital in the attracting country, and the envisaged spillover effects will close the existing technology gap in the host economy, and improve the quality of human capital, while fuelling development in less developed industrial sectors of the economy.

Despite the complexity that pervades FDI initiative, a converging point is reached in consonance with the focus area of this study. To that extent, this study is based on the OLI paradigm of Dunning (1981). The basic principles of Dunning's OLI paradigm revolve around the Ownership-specific factors $(\mathrm{O})$, Locationspecific advantage considerations (L), and the Internalisation theory by market failure factors (I). The practical underpinning of this theory buttresses the conflicting motives of the MNCs and the expectations of the home and host country governments mentioned in the previous paragraph. According to Dunning, the eclectic paradigm or the ownership-location-internalisation (OLI) framework lends credence to the investor motives of MNCs and the reactions of home and host governments to FDI. This study, premised on the impact of regulatory framework on FDI inflow, will be restricted to the second and third parts of the OLI model. The study will adopt the locationspecific advantage considerations and the internalisation theory by market failure factors, on the ground that these two considerations have been identified as the major regulatory determinants of FDI behaviour in the developing countries (an economic grouping in which most African countries belong).

As such, the location-specific advantage in this regard will be viewed from the perspectives of government policy, especially monetary and fiscal policies. These considerations will be primed on the efficiency of the political institutions in the host country to formulate relevant investment-related fiscal and monetary policies. These factors are considered in the following paragraphs, which examine the determinants of FDI behaviour in the African context.

\subsection{Model specification}

The dependent variable in this research is the ratio of FDI flows to GDP. This variable has been used in previous studies (Alba, Park \& Wang, 2009; Alfaro et al., 2004; Asiedu, 2002). The variable is adjudged the most efficient measure of FDI inflow because it captures the relative contribution of FDI to GDP. The explanatory variables are identified as trade openness, fiscal balance, exchange rate, inflation, interest rates, government spending and corporate tax. Country resource dummy is introduced to control for the variability in FDI behaviour that is resource-induced. This is essential given that only four (South Africa, Egypt, Nigeria and Morocco) of the 53 African countries attract diversified FDI that are both resources and service-related. To do this, a dummy variable of ' 1 ' is introduced for countries endowed with resources that are generally considered of strategic interest to the foreign investors. Evidence suggests that crude oil, coal, platinum and gold dominate that list in Africa. Further, a dummy of ' $\theta$ ' will be introduced for countries that do not possess those resources.

In addition, while trade barriers and economic openness are treated separately in Chakrabarti's study, it is my view that trade barriers are restrictive measures that inhibit free trade, and as such, can be measured by the variables that evaluate the degree of economic openness. In other words, the amount of trade restrictions applied by an economy determines the extent to which the economy is opened to international trade (Asheghian, 2004; UNCTAD, 2009), which prompted using the ration of mercantile trade to GDP as a proxy. Hence, the model specification for this research is as follows: 


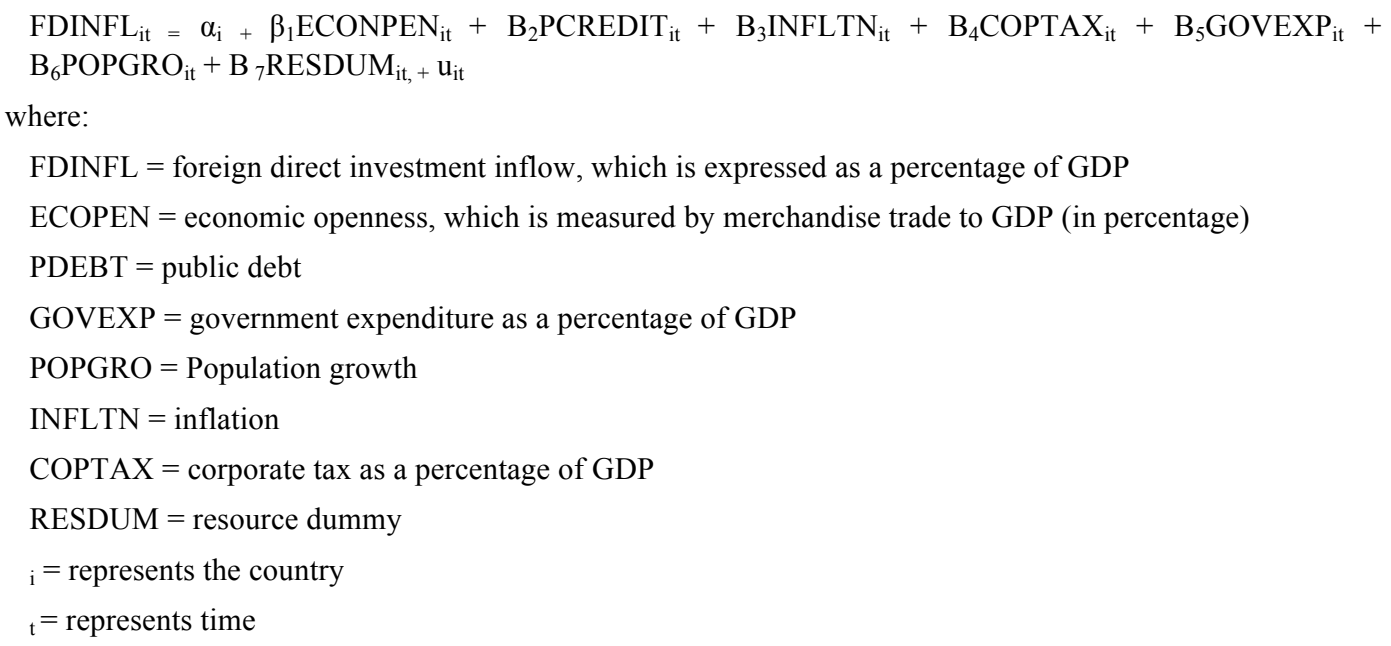

\section{5 \\ Defining the explanatory variables}

Evidence abounds on the importance of economic openness as a determinant of the attractiveness of a country to inflow of FDI. While some studies are inconclusive about the impact of trade openness (Wheeler \& Mody, 1992; Ponce, 2006), a few other studies suggest a strong relationship (Culem, 1988; Kandiero \& Chitiga, 2003; Klasra, 2009). Economic openness depicts the extent to which an economy is opened to foreign markets, through its active participation in trade and investment. In this research, economic openness is proxied by the ratio of merchandise trade to GDP. This is so because economic protection is effected through the application of tariffs, especially on manufactured products, but other services and products are largely not immune to this statutory instrument of trade restriction. To that extent, the strength of a nation's protectionist measures would determine its level of trade (import and export) in merchandise. It must be acknowledged that quite a number of previous studies have proxied economic openness by the ratio of exports plus imports to GDP (Lunn, 1980; Elbadawi \& Mwega, 1997; Billington, 1999).

Inflation (an indication of changes in the prices of basic consumer goods over the year under consideration) is used in this study as a measure of the impact of price changes in the domestic market on the consumption of both locally manufactured products and imported products. Theories that relate to household consumption have established an inverse relationship between inflation and consumption patterns of households in the affected countries (Dunning, 1981; Hill, 2013).

Fiscal balance, which is proxied by public debt, reflects the stability of macroeconomic framework. This variable (along with government consumption) has been used in various studies to measure government policy (Kok \& Ersoy, 2009). The argument in support of this variable is that a stable and healthy economy is expected to minimise budget deficit (public debt), given that a sudden recall of short-term loans by lenders may trigger instability (Ito, 1999). To this extent, the level of government deficit may be an indication of the financial resilience of a country and the long-run stability of the macroeconomic fundamentals. It is widely suggested that the cost of capital is reduced if the probability of market failure is minimal, that is, the higher the risks profile of the country, the higher the cost of capital. As such, a country with perceived stable macroeconomic fundamentals is adjudged a stable investment environment. The same explanation goes for government expenditure, which has also been used in previous studies to measure government policy. Evidence suggests that government expenditure directed towards production functions are generally growth-inductive while recurrent spending are essentially regarded as wasteful.

The administration of corporate tax in a 
country may reflect the strategic interest of the country in local manufacturing, and more importantly, the manufacturing areas that are of strategic importance to the economy. While high corporate tax is used to discourage investment in certain sectors, low corporate tax is expected to boost productivity and investment in certain sectors of the economy. A country that is characterised by high corporate tax may be considered unattractive to foreign investment, thereby limiting competition among the economic agents. This may be a deliberate attempt by a government to protect economic incumbency as a way of retaining economic rents among a few market participants. In addition, the introduction of population growth to the equation is justified on the ground that this variable is considered an important determinant of market size, especially if the population size or population growth potential is commingled with a rise in income level/potential improvement in the standard of living.

\section{6}

\section{Data analysis}

\subsection{Source of data}

The data used in this analysis was generated from the World Bank African Development Indicators (ADI), a statistical arm of the World Bank. The data covers a period of between 1980 and 2008 for 46 African countries. The other African countries were eliminated from the analysis because data could not be generated for most of the variables used in the study, especially for the dependent variable.

\subsection{Analysis}

The panel regression estimation technique is applied in this study. A series of diagnostic techniques were undertaken to ensure reliability and to cater for sensitivity. Attempts were also made to eliminate redundant variables and to cater for the possibility of omitted variables. To start with, the unit root test was conducted in order to determine the order of integration in the series. According to the literature, the unit root test is also a precursor for the Granger Causality test. The Granger Causality test is based on the asymptotic theory, which prescribes the stationarity of variables in the same order of integration (Granger, 1988).

The unit root test is hereby conducted using the Levin, Lin and Chu (2002) technique (LLC). The LLC technique is very popular in the literature and it is regarded as the most reliable test in estimating panel data. This is so because the technique generally accommodates fixed effects, individual deterministic trends and heterogeneous serially correlated errors in the series (Baltagi, 2008). According to this author, the length of the time series, which is held as infinity, is crucial for determining asymptotic properties of estimators. Further, the approach provides a good approximation for the empirical distribution of the test statistic even in relatively small samples (for example where $\mathrm{N}$ ranges between 10 and 250 , and $\mathrm{T}$ between 25 and 250) (Baltagi, 2008) as in the case of this study. As informed by the unit root test, all the variables used are integrated in order 1 , thereby justifying the application of the orthogonal deviation technique (which is more efficient than differencing the data).

A series of other diagnostic methods are also adopted. One of the widely used diagnostic techniques is the random/fixed effect tests as well as test for redundant variables. In the first instance, the Hausman test is conducted to determine the applicable dummy (period or cross-sectional effects). This test helps to correct for possible autocorrelation between the regressor variables and the error terms. Further, the redundancy variable test was conducted. The stepwise regression approach was used (not reported), to test the explanatory power of the explanatory variables, thereby determining their contribution to the predictability of the model.

Also, the White diagonal standard errors and covariance technique is used to cater for the standard errors in such a way that they are robust to arbitrary serial correlation and timevarying variances in the disturbances. In essence, the White diagonal robust coefficient variance estimator is designed to accommodate arbitrary serial correlation and time-varying variances in the disturbances of an econometric estimation, especially in the panel regression environment. It should be noted, however, that the use of diagnostics reduces 
the number of panel units in the estimation, and as such, influences the explanatory power of the model.

More importantly, the Durbin-Watson statistics that are contained in the generalised method of moments (GMM) technique are used as a diagnostic measure. This application is used to test for potential first order autocorrelation in variables. Strong negative numbers or high positive numbers that are above 2 generally suggest that the null hypothesis be rejected on the basis that there is autocorrelation among the variables used. To address possible endogeneity in the series, estimation instruments are restricted to one. In addendum to the regression analysis, it is considered important to ascertain the strength and direction of relationship among variables. As such, the Granger Causality test is applied. The following paragraphs contain the result of the econometric estimations, beginning with the dynamic panel estimation that is presented in Table 1:

Table 1

Determinants of FDI flow to Africa (dependent variable - FDINFL)

\begin{tabular}{|c|c|c|c|c|c|c|c|}
\hline & I & II & III & IV & $\mathbf{V}$ & VI & VII \\
\hline GOVEXP & $\begin{array}{c}-0.127359 \\
(0.03299)^{\star \star \star}\end{array}$ & & & & & & \multirow{2}{*}{$\begin{array}{c}0.012098 \\
(0.00214)^{\star \star \star}\end{array}$} \\
\hline PDEBT & & $\begin{array}{l}-0.037392 \\
\left(0.01823^{* *}\right.\end{array}$ & & & & & \\
\hline COPTAX & & & $\begin{array}{c}-0.001413 \\
(0.00 .3441)\end{array}$ & & & & \multirow{2}{*}{$\begin{array}{c}-0.00276 \\
(0.0000)^{\star \star *}\end{array}$} \\
\hline ECOPEN & & & & $\begin{array}{c}0.064129 \\
(0.01038)^{\star * *}\end{array}$ & & & \\
\hline POPGRO & & & & & $\begin{array}{c}-0.870171 \\
(0.22967)^{\star * *}\end{array}$ & & \\
\hline INFLTN & & & & & & $\begin{array}{l}-0.000336 \\
(0.00031)\end{array}$ & \\
\hline Observation & 1238 & 1209 & 1173 & 1333 & 1331 & 1238 & 1130 \\
\hline $\begin{array}{l}\text { Sargan Test } \\
(\text { Prob >chi2) }\end{array}$ & 0.145 & 0.197 & 0.330 & 0.376 & 0.201 & 0.358 & \\
\hline $\begin{array}{l}\text { Number of } \\
\text { countries }\end{array}$ & 46 & 46 & 46 & 46 & 46 & 46 & 46 \\
\hline
\end{tabular}

Robust standard errors are in parentheses. ${ }^{* *} p<0.01,{ }^{* *} p<0.05,{ }^{*} p<0.1$. Cross-section weights instrument weighting matrix and Convergence was achieved after 1 weight iterations. Cross-section weights (PCSE) standard errors \& covariance (no d.f. correction). Maximum lags of dependent and predetermined variables for use as instruments are limited to 1.

From Table 1, columns $I$ to $V$ contain the output for each of the explanatory variables as entered separately, while column VI contains the output for the interacted variables. The result of dynamic panel estimation that is contained in Table 1 suggests that all the variables tested in this study (except for corporate tax) are regarded as important considerations for attracting FDI to African countries. With the exception of public debt, the remaining three variables (government expenditure, economic openness and population growth) are statistically significant at 1 percent level. Although, corporate tax (COPTAX) expectedly bears a negative coefficient with inflow of FDI, it is statistically insignificant. Surprisingly, government expenditure (GOVEXP) is statistically significant but bears a negative coefficient with the dependent variable. This relationship indicates that an increase in government consumption may reduce the attractiveness of Africa to inflow of FDI. These results are robust to low standard errors.

Four regulatory variables are interacted (in pairs) to investigate the explosive nature of the estimation. According to column VI, government expenditure (GOVEXP) and public debt (PDEBT) are interacted. The robust standard error $(0.0021)$ and the $p$-value of the estimation $(0.0000)$ attest to the statistical significance of the result. Further, the result of the interaction indicates that these variables jointly affect (positively) the attractiveness of Africa to inflow of FDI. The result of the other interacted variables (corporate tax - COPTAX and economic openness - ECOPEN) suggests 
the same level of statistical significance but the result bears negative coefficient.

As a test of robustness, two stage least squares (2SLS) estimation technique is also applied. The result of the 2 SLS is presented in
Table 2. Table 2 lends credence to the robustness of the estimation, as it espouses the weighted statistics as compared to the standardised estimation process that is adopted in Table 1:

Table 2

Determinants of FDI flow to Africa (Dependent Variable - FDINFL)

\begin{tabular}{|c|c|c|c|c|c|c|c|}
\hline & $\mathbf{I}$ & II & III & IV & V & VI & VII \\
\hline GOVEXP & $\begin{array}{l}-0.154687 \\
(0.0446)^{\star * *}\end{array}$ & & & & & & \multirow{2}{*}{$\begin{array}{c}0.004587 \\
(0.002607)^{\star *}\end{array}$} \\
\hline PDEBT & & $\begin{array}{l}-0.003225 \\
(0.0303)^{\star \star \star}\end{array}$ & & & & & \\
\hline COPTAX & & & $\begin{array}{l}-0.00097 \\
(0.00007)\end{array}$ & & & & \multirow{2}{*}{$\begin{array}{c}-0.000078 \\
(0.000097)^{\star *}\end{array}$} \\
\hline ECOPEN & & & & $\begin{array}{c}0.077236 \\
(0.0191)^{\star * \star}\end{array}$ & & & \\
\hline POPGRO & & & & & $\begin{array}{c}0.057398 \\
(0.252260)\end{array}$ & & \\
\hline INFLTN & & & & & & $\begin{array}{l}-0.000132 \\
(0.000162)\end{array}$ & \\
\hline Observation & 1238 & 1209 & 1173 & 1333 & 1331 & 1238 & 1130 \\
\hline $\begin{array}{l}\text { Sargan Test } \\
(\text { Prob >chi2) }\end{array}$ & 0.324 & 0.459 & 0.117 & 0.269 & 0.145 & 0.876 & 0.102 \\
\hline $\begin{array}{l}\text { Number of } \\
\text { countries }\end{array}$ & 46 & 46 & 46 & 46 & 46 & & 46 \\
\hline
\end{tabular}

Robust standard errors are in parentheses. ${ }^{* * *} p<0.01,{ }^{* *} p<0.05,{ }^{*} p<0.1$. Cross-section weights instrument weighting matrix and Convergence was achieved after 1 weight iterations. Cross-section weights (PCSE) standard errors \& covariance (no d.f. correction). Maximum lags of dependent and predetermined variables for use as instruments are limited to 1.

Interpreting the 2SLS analysis contained in Table 2, the Sargan test suggests that none of the variables is statistically significant, thereby negating the null hypothesis that the overidentifying restrictions are valid. Looking at individual variables, three of the six explanatory variables are statistically significant, and four bear negative coefficients. Government expenditure (GOVEXP), public debt (PDEBT), corporate tax (COPTAX), and inflation (INFLTN) all bear negative coefficients. The inverse relationship between these variables and the dependent variable are indication that these variables have the tendency to affect negatively the attractiveness of Africa to inflow of FDI. Further, the positive coefficients borne by economic openness (ECOPEN) and population growth (POPGRO), suggest the possible realisation of an improvement in the attractiveness of Africa to inflow of FDI the more the governments of the sampled countries initiate economic liberalisation and market size. However, the fact that government expenditure, public debt and economic openness are statically significant buttresses their relevance as the major macroeconomic policies of relevance.

The interaction of government expenditure and public debt economic openness and corporate tax expectedly bears a negative coefficient and is statistically significant. The interaction of these variables suggests that FDI inflow would increase by increasing government spending, and that an increase in budget deficit will not discourage inflow of FDI to Africa. However, the interaction of corporate tax and economic openness indicates that government intervention is required to further liberalise the economy and reduce corporate tax in order to improve the attractiveness of Africa to inflow of FDI.

A comparison of the two tables (Tables 1 and 2) indicates conspicuous similarity among the results except in instances where the level of statistical significance of the variables is stronger than the other. For instance, the statistical significance of the interacted variables is stronger in Table 1 than in Table 2. Further, 
population growth bears a negative coefficient in Table 1, and positive in Table 2. Largely, the two estimations yield very similar results.

Having presented the results of the panel estimation, it is considered essential to establish the direction of causality among the variables that are used in the estimation. The analysis of the (Granger) causality test is presented in the paragraphs that follow. The null hypothesis of causality test holds if the probability statistics do not fall within the range of 0.01 or 0.05 , and vice versa.

Table 3

Granger causality estimation

\begin{tabular}{|l|l|c|}
\hline \multicolumn{2}{|c|}{ Direction of causality } & Statistical significance \\
\cline { 2 - 3 } & FDINFL & 0.0044 \\
\hline GOVEXP & GOVEXP & 0.2187 \\
\hline FDINFL & FDINFL & 0.9865 \\
\hline PCREDIT & PCREDIT & 0.4851 \\
\hline FDINFL & FDINFL & 0.000003 \\
\hline ECOPEN & ECOPEN & 0.100026 \\
\hline FDINFL & FDINFL & 0.7250 \\
\hline COPTAX & COPTAX & 0.8358 \\
\hline FDINFL & FDINFL & 0.1090 \\
\hline POPGRO & POPGRO & 0.0881 \\
\hline FDINFL & & 1334 \\
\hline Observation & & 46 \\
\hline Number of countries & 46 & \\
\hline
\end{tabular}

F-statistics are in parentheses. ${ }^{* * *} p<0.01,{ }^{* *} p<0.05,{ }^{*} p<0.1$.

From Table 3, only three directional relationships can be established among the variables. For instance, government expenditure is found to be capable of enhancing the attractiveness of Africa to inflow of FDI. As suggested by the literature (Ashegian 2004; Akinkugbe, 2005; Caves, 2007), the expenditure has to be directed towards infrastructure development. Also, economic openness is found to have a direct causal relationship with inflow of FDI. This further buttresses the possible impact of economic liberalisation as an important determinant of the attractiveness of Africa to inflow of FDI. Conversely, there is a reverse causality between inflow of FDI and population growth. This may imply that an increase in inflow of FDI may precipitate population growth. Arguably, an increase in income level, which may be attributed to inflow of FDI, may result in creating a larger consumer market size.

\section{7}

\section{Conclusion}

The literature identifies some of the important determinants of the destination of MNCs' offshore investment. While the explanatory power of a few of the determinants of the direction of FDI flows has been established, the explanatory power of a few others remains contentious. In this research, the conclusion can be drawn that most of the MNCs that venture into African countries premise their offshore investment principles on macroeconomic fundamentals, essentially, socioeconomic development. The major determinants identified in this study are macroeconomic policies. Factors like government expenditure, public debt, economic openness and corporate tax are found to be important to attract FDI to Africa. These findings conform to the postulation of Dunning's (1981) OLI theoretical a priori. According to these findings, the locationspecific advantage considerations (such as economic liberalisation, corporate tax and market size) and the internalisation theory by market failure factors (such as public debt) appear to be important determinants of FDI flow to Africa.

According to international trade theories, foreign investors venture abroad mainly to reap location-specific advantages. Theory suggests 
that the overarching determinants of the direction of offshore investment by MNCs are micro- and macroeconomic frameworks of the country. As such, economies with a stable political economy are more attractive than those countries without such a conducive investment climate.

Evidence suggests that foreign investors are generally backed by the home country to ensure easy access into the foreign country, to leverage operational risks, as well as to ensure an enduring support from the host government (Caves, 1996; Asheghian, 2004; Alba, Park \& Wang, 2009). Further, while this study suggests that institutional (macroeconomic) factors play prominent roles in attracting FDI into Africa, investor motives are also seen to be keen in this regard. Investors are only positively disposed towards long-term commitment to a country or region that offers sustainable macroeconomic peacefulness, which is why most of their commitments in Africa take the form of mergers and acquisitions (UNCTAD, 2013).

The saturation in consumer markets across the West suggests that it is imperative to refocus the entry strategies of these multinationals in Africa. The reappraisal of the investors' entry strategy to Africa, essentially the embracement of offshore production facilities in the form of greenfield investment, is seen to be a more expedient approach as demonstrated by Toyota in the United States. It may equally be important to include spillover of competency, local capacity development and technological spillover in the overseas expansion strategies. While the current investment strategy may be appropriate, its appropriateness is only sustainable to the extent that these institutional frameworks remain favourable to MNCs.

More importantly, African leaders should rethink their administrative and institutional conscripts in a way that engenders efficiency and efficacy. It is argued that lean and transparent government spending, coupled with accountability, will not only lure greenfield foreign investors. Increasing government spending on capital projects that are geared towards infrastructural development is more likely to attract FDI. Further, policy initiatives are required to further liberalise economies in African countries, although the liberalisation process should be well guided in order to create appropriate safety nets for potential victims of that process and its antecedent outcomes.

\section{References}

ADAM, A.N. \& TWENEBOAH, G. 2009. Foreign direct investment and stock market development: Ghana's evidence. International Research Journal of Finance and Economics, 26:178-85.

AKINKUGBE, O. 2005. A Two-part econometric analysis of foreign direct investment flows to Africa. Netherlands: Kluwer Law International.

ALBA, J.D., PARK, D. \& WANG, P. 2009. The impact of exchange rate on FDI and the interdependence of FDI over time. ADB Economics Working Paper Series, Number 164.

ALFARO, L., CHANDA, A., KALEMLI-OZCAN, S. \& SAYEK, S. 2004. FDI and Economic Growth: The role of local financial markets. Journal of International Economics, 64(1):89-112.

ASIEDU, E. 2002. On the determinant of foreign direct investment to developing countries: Is Africa different? World Development, 30(1):107-19.

ASHEGHIAN, P. 2004. Determinants of economic growth in the United States: The role of foreign direct investment. The International Trade Journal, 18(1):63-83.

BALTAGI, B.H. 2008. Econometrics analysis of panel data (4th ed.) Chichester: John Wiley and Sons Ltd. BARRO, R. \& SALA-I-MARTIN, X. 1995. Economic growth. New York: McGraw-Hill.

BILLINGTON, N.M. 1999. The Location of foreign direct investment: An empirical analysis. Journal of Applied Economics, 31:65-76.

BUCKLEY, P.J. 1990. International investment, New York: Edward Elgar.

CAVES, R.E. 1996. Multinational enterprise and economic analysis $\left(2^{\text {nd }}\right.$ ed.) London: Cambridge University Press. 
Caves, R.E. 2007. Multinational enterprise and economic analysis ( $3^{\text {rd }}$ ed.) Boston: Cambridge University Press

CHAKRABARTI, A. 2001. The determinants of foreign direct investment: Sensitivity analyses of crosscountry regressions. Kyklos, 54(1):89-114.

CORREA, C.M. \& KUMAR, N. 2003. Protecting foreign investment: Implications of a WTO regime and policy options. London: Zed Books Ltd.

CULEM, C.G. 1988. The locational determinants of direct investment among industrialised countries. European Economic Review, 32:885-904.

DUNNING, J.H. 1981. International production and the multinational enterprise. London: George Allen and Unwin.

DUNNING, J.H. 1988. Multinationals, technology and competitiveness. London: Unwin Hyman.

ELBADAWI, I. \& MWEGA, F. 1997. Trade reform and regional integration in Africa. Papers presented at the IMF, African Economic Research Consortium Seminar on Trade Reform and Regional Integration in Africa, December 1, Washington, D.C.:369-94.

GRANGER, C.W.J. 1988. Some recent developments in the concept of causality. Journal of Econometrics, 39:199-211.

HILL, C.W.L. 2013. International business: Competing in the global marketplace (9th ed.) McGraw-Hill: Irwin.

HOOD, N. \& YOUNG, S. 1979. Economics of multinational enterprise. London: Longman.

ITO, T. 1999. Capital flows in Asia. NBER Working Paper Series, No: 7134.

KANDIERO, T. \& CHITIGA, M. 2003. Trade openness and foreign direct investment in Africa. Economic Society of Southern Africa 2003 Annual Conference, 17-19 September 2003 Cape Town, South Africa. KLASRA, M.A. 2009. Foreign direct investment, trade openness and economic growth in Pakistan and Turkey: An investigation using bounds test. Qual Quant Research Note. Springer Science+Business Media B.V.

KOK, R. \& ERSOY, B.A. 2009. Analysis of FDI determinants in developing countries. International Journal of Social Economics, 36(1/2):105-123.

KORTH, C.M. 1985. International Business Environment and Management $\left(2^{\text {nd }}\right.$ ed.) New Jersey: PrenticeHall.

LEVI, M.D. 2009. International finance (5 ${ }^{\text {th }}$ ed.) London: Routledge.

LEVIN, A., LIN, C. \& CHU, C-J. 2002. Unit root tests in panel data: Asymptotic and finite-sample properties. Journal of Econometrics, 108:1-24.

LUNN, J, 1980. Determinants of US direct investment in the EEC: Further evidence. European Economic Review, 13:93-101.

PENG, M.W. 2009. Global business. New York: South-Western Cengage Learning.

PONCE, A.F. 2006. Openness and foreign direct investment: The role of free trade agreements in Latin America. MPRA Paper No. 8858:1-26.

PORTER, M.E. 1990. The comparative advantage of nations. New York: Free Press.

RIVERA-BATIZ, L.A. \& OLIVA, M.A. 2003. International trade: Theory, strategies, and evidence. New York: Oxford University Press.

SCHMITZ, H. 2007. Reducing complexity in the industrial policy debate. Development Policy Review, 25(4):417-428.

STEERS, M.R. \& NARDON, L. 2006. Managing in the global economy. New York: M.E. Sharpe, Inc. STIGLITZ, J.E. 2002. Globalization and its discontents. New York: W.W. Norton \& Company.

STIGLITZ, J.E. \& CHARLTON, A. 2005. Fair trade for all. New York: Oxford University Press.

THE UNITED NATIONS CONFERENCE ON TRADE AND INVESTMENT (UNCTAD). 2013. World investment report: Global value chains: Investment and trade for development. New York and Geneva: The United Nations Conference and Trade and Development.

THE UNITED NATIONS CONFERENCE ON TRADE AND DEVELOPMENT (UNCTAD). 2009. World investment report. Transnational corporations, agricultural production and development. New York and Geneva: The United Nations. 
WHEELER, D. \& MODY, A. 1992. International investment locational decisions: The case of US firms. Journal of International Economics, 33:57-76.

Appendix A: List of African countries covered in the study

\begin{tabular}{|c|c|c|c|}
\hline 1 & Algeria & 24 & Lesotho \\
\hline 2 & Angola & 25 & Liberia \\
\hline 3 & Benin & 26 & Madagascar \\
\hline 4 & Botswana & 27 & Malawi \\
\hline 5 & Burkina Faso & 28 & Mali \\
\hline 6 & Burundi & 29 & Mauritania \\
\hline 7 & Cameroon & 30 & Mauritius \\
\hline 8 & Cape Verde & 31 & Morocco \\
\hline 9 & Central African Republic & 32 & Mozambique \\
\hline 10 & Chard & 33 & Namibia \\
\hline 11 & Comoros & 34 & Niger \\
\hline 12 & Congo, Dem. Rep. & 35 & Nigeria \\
\hline 13 & Congo, Rep. & 36 & Rwanda \\
\hline 14 & Cote d'Ivoire & 37 & Senegal \\
\hline 15 & Egypt, Arab Rep. & 38 & Seychelles \\
\hline 16 & Equatorial Guinea & 39 & Sierra Leone \\
\hline 17 & Ethiopia & 40 & South Africa \\
\hline 18 & Gabon & 41 & Sudan \\
\hline 19 & Gambia, The & 42 & Swaziland \\
\hline 20 & Ghana & 43 & Togo \\
\hline 21 & Guinea & 44 & Tunisia \\
\hline 22 & Guinea-Bissau & 45 & Uganda \\
\hline 23 & Kenya & 46 & Zambia \\
\hline
\end{tabular}

